\title{
Focus on the fire of life
}

Citation for published version (APA):

Saris, W. H. (2004). Focus on the fire of life. Current Opinion in Clinical Nutrition and Metabolic Care, 7(6), 595-597. https://doi.org/10.1097/00075197-200411000-00002

\section{Document status and date:}

Published: 01/01/2004

DOI:

10.1097/00075197-200411000-00002

Document Version:

Publisher's PDF, also known as Version of record

\section{Please check the document version of this publication:}

- A submitted manuscript is the version of the article upon submission and before peer-review. There can be important differences between the submitted version and the official published version of record.

People interested in the research are advised to contact the author for the final version of the publication, or visit the DOI to the publisher's website.

- The final author version and the galley proof are versions of the publication after peer review.

- The final published version features the final layout of the paper including the volume, issue and page numbers.

Link to publication

\footnotetext{
General rights rights.

- You may freely distribute the URL identifying the publication in the public portal. please follow below link for the End User Agreement:

www.umlib.nl/taverne-license

Take down policy

If you believe that this document breaches copyright please contact us at:

repository@maastrichtuniversity.nl

providing details and we will investigate your claim.
}

Copyright and moral rights for the publications made accessible in the public portal are retained by the authors and/or other copyright owners and it is a condition of accessing publications that users recognise and abide by the legal requirements associated with these

- Users may download and print one copy of any publication from the public portal for the purpose of private study or research.

- You may not further distribute the material or use it for any profit-making activity or commercial gain

If the publication is distributed under the terms of Article $25 \mathrm{fa}$ of the Dutch Copyright Act, indicated by the "Taverne" license above, 


\section{Focus on the fire of life \\ Wim H. M. Saris}

Nutrition and Toxicology Research Institute Maastricht, NUTRIM, University of
Maastricht, Maastricht, The Netherlands

Correspondence to Wim H. M. Saris, Department of Human Biology, Nutrition and Toxicology Research Institute NUTRIM, PO Box 616, 6200 MD Maastricht, The Netherlands

Tel: +31 43 3881619; fax: +31 43 3670976; e-mail: W.Saris @hb.unimaas.nl

Current Opinion in Clinical Nutrition and Metabolic Care 2004, 7:595-597

Abbreviations

NEAT non-exercise activity thermogenesis

TDEE total daily energy expenditure

(C) 2004 Lippincott Williams \& Wilkins 1363-1950

\section{Introduction}

In 1961 Max Kleiber published the book The Fire of Life [1]. It is still one of the classics in the field of animal and human bioenergetics. In his book he focussed on the parallel between animal and human life and fire, emphasizing the generalizations of biophysics rather than the differentiations of biochemistry. Life involves much more than chemical potential, work and heat. Modern nutrition is concerned with more than the supply of energy, yet energy transfer remains one of the basics in physiology in general and of nutrition in particular. Especially nowadays, with the unravelling of the human genome providing the first glimpse of candidate genes in bioenergetics, it becomes more and more clear that the concluding remark from Charles Darwin's book The Origin of Species really points to the fire of life: 'The evolution of higher animals directly follows....from the war of nature, from famine and death...' [2].

In the last century nutritional sciences research has been devoted for a large part on the effects of malnutrition since this was the greatest challenge related to health and disease in the world. It looks as though, for the coming decades and maybe the whole century, overfeeding will dominate the nutritional research agenda observing the morbidity and mortality statistics in the world. Again it all has to do with the bioenergetics and the consequences for the quality of life.

\section{Thrifty genes and the observed variation in bioenergetics}

In 1960 Neel postulated for the first time the so-called thrifty gene theory based on his research in diabetes [3]. The selection period that has covered almost $100 \%$ of human life on earth has been dominated by periods of feast and famine, which has facilitated the ability to lay down extra adipose tissue and this survival trait from ancient times has become a treat instead of a redundancy trait in the modern world. Especially, those who could build up large quantities of adipose tissue in periods of feasting and gorging were the ones who survived long periods of famine. Darwin had already observed this most pervasive selection force of species.

Therefore information about the variation in bioenergetics is of importance to understand better the origin of a number of today's chronic diseases, such as diabetes, obesity and cardiovascular disease.

In the feed industry it has already been known for a long time that there are large differences in energy efficiency between animals within species [4]. But even in humans we now have solid data that there is large variation in the handling of excess energy intake [5,6]. The classical overfeeding study in identical twins from Bouchard et al. clearly showed a threefold difference in the ability to lay down excess calories in weight [5]. Based on a more detailed description by Tremblay et al., the energy efficiency was calculated to range from 33 to about $100 \%$ in these 12 identical twins (Table 1) [7]. Also in the shorter, overfeeding study of Levine et al. [6] with young men, a similar variation in energy efficiency was found.

Considering that the selection process has taken place over many millions of generations it is remarkable that the differences have their origins in the genetic variations (single nucleotide polymorphisms) in particular genes, or maybe in thousands of genes. The unravelling of the mystery of the fire of life is at full speed now with all the high throughput genomic capacity. Nevertheless, at the same time we need to update our physiological information in order to link the genetic and molecular know-how to the genotypic function.

\section{The variation in minimal and maximal metabolism}

In order to make comparisons between the energy metabolism of individuals within or between species, the conditions under which the measurements are based must be standardized. This is achieved by attempting to measure a minimum rate of energy expenditure free of effects of any controllable factors known to increase it. 
Table 1. Effects of 100 days' overfeeding with $1000 \mathrm{kcals}$ per day on weight gain and energy efficiency defined as percentage of body energy gain versus excess energy intake

\begin{tabular}{lccc}
\hline & Mean & Range & Theoretical gain \\
\hline Body weight gain $(\mathrm{kg})$ & 8.1 & $4.3-13.3$ & 14.7 \\
Fat gain $(\mathrm{kg})$ & 5.4 & $2.9-8.9$ & \\
${\text { Energy efficiency }(\%)^{\mathrm{a}}}$ & 63 & $33-102$ & \\
\hline
\end{tabular}

${ }^{a}$ Body energy gain was derived from densitometric measurements assuming that the energy equivalent of fat was $38.9 \mathrm{MJ} / \mathrm{kg}$ and that of fat free mass was 4.3 MJ/kg. Data from Bouchard et al. [5] and Levine et al. [6].

Such factors include muscular exercise, the consumption of food and its subsequent metabolism and the physical environment. The object of standardization is to ensure comparability of estimates rather than to establish some absolute minimum value of metabolism [4].

In many situations it is impractical to fast or feed humans under a strictly controlled way as defined for measuring basal metabolic rate, yet some standardized estimate of metabolism is required. Metabolism determined without the criteria applied for the fasting or feeding state, but with the remaining conditions listed by Benedict being met, is termed the resting metabolic rate.

This is one of the primary components in the factors contributing to the variation in total daily energy expenditure (TDEE) reviewed in the paper in this issue by Donahoo, Levine and Melanson. They conclude that the coefficient of variation of all components of TDEE is rather reproducible. TDEE varies many-fold in humans, not due to variation in resting metabolic rate, diet induced thermogenesis or exercise thermogenesis, but due to variations in non-exercise activity thermogenesis (NEAT). A variety of factors impact NEAT of which, most probably, genetic factors including sex are dominant. In the light of the emerging obesity epidemic, further elucidation of the potential candidate genes and their variations is needed. So far, from the genetic and molecular level, it can more or less be considered as a black box. Recently Ukkola and Bouchard [8] reviewed the findings of an analysis of a panel of candidate genes to explain the variation in response of the twin overfeeding study. Among the most significant findings, an adipsin polymorphism was associated with the increases in body weight, total fat mass and subcutaneous fat. In addition the beta-2 adrenergic receptor gene Gln27Glu polymorphism showed a strong association with the gains in body weight and subcutaneous fat. The changes in the insulin parameters brought about by the long-term overfeeding were influenced most consistently by the leptin receptor (LEPR) Gln223Arg gene variant. Further research with larger sample sizes should make it possible to identify the specific contribution of DNA sequence variations to the individual response in energy efficiency.

Changing the focus on the maximum of human metabolism Westerterp and Plasqui describe in their contribution to this issue the upper limits of human energy expenditure. Based on the large cross-sectional database on measurements using the very valid doubly labelled water method, they conclude that in the normal population the upper limit of the physical activity index (equal to total energy expenditure as a multiple of resting metabolic rate) is about 2.5. However in a large part of the population the level is only around 1.6. The best current estimates are that the physical activity of ancestral humans averaged about $1000 \mathrm{kcal}$ per day and that their caloric need was about $3000 \mathrm{kcal}$ per day, representing today's demonstrated upper limit of the physical activity index of around 2.3 [9]. This indicates that we have a long way to go before our modern physical activity habits fit within the metabolic capacities of our gene pool selected at that ancient time.

\section{Metabolic consequences of a high or low fire of life}

In the 1930s it had already become clear that caloric restriction has effects on retarding the effects of ageing and extending life. Lowering your fire will effect your life. In this section, Smith, Heilbronn and Ravussin review the existing knowledge on the link between calorie restriction and ageing. An overwhelming number of studies have shown that calorie restriction extends both the median and maximal lifespan in a variety of lower species such as yeast, worms, fruit flies, fish, rats and mice.

The mechanisms of this lifespan extension via calorie restriction are not yet fully elucidated, but possibly involve significant alterations in energy metabolism, oxidative damage, the sympathetic nervous system and in particular insulin/insulin-like growth factor signalling. In particular the new genomics technology of microarray gene expression have brought much light onto the basic mechanisms of how a lower fire is linked to life, and particular extension of life. New genes such as DAF16, never linked before with the energy metabolic routes, have turned out to be of crucial importance. However Smith and co-authors conclude that only controlled human trials involving long-term calorie restriction can ultimately link observed alterations from body weight and composition down to changes in molecular pathways and gene expression, with their possible effects on the biomarkers of ageing.

How much overfeeding restricts life is becoming a hot topic in nutritional research. Tappy describes in his review the metabolic consequences of this currently so 
frequently observed phenomenon in the real world. It is interesting to observe that, in particular, NEAT is activated under situations of overfeeding. Since this factor is subjected to a large in-between-subject variation further research to elucidate the underlying molecular mechanisms is of importance. Overfeeding also alters the pathways used for carbohydrate storage by increasing denovo lipogenesis. This pathway is not considered to be of physiological importance in humans in relation to the excess of energy [10]. Long-term overfeeding, however, could perhaps alter metabolism in such a way that denovo lipogenesis occurs at a low, hardly detectable level, yet which may contribute to the yearly increment in body fatness.

The link between insulin/insulin-like growth factor signalling in situations of calorie restriction and the observed insulin resistance as a consequence of overfeeding is of interest and puts this nutrient/energy signalling hormone at the centre of interest when studying the fire of life.

This was originally also thought to be the case when the hormone leptin was discovered in 1995. The story of leptin is salutary and one which should give pause to all of those who believe that sequencing the human genome will provide an easy way of identifying the key molecular pathways in the cause of diseases.

Hukshorn and Saris review the existing knowledge on the relation between leptin and energy expenditure. They conclude that there is no evidence that in humans leptin has an effect on energy expenditure. This is in contrast to all the compelling evidence in rodents. Originally, the implications for human physiology and pathophysiology seemed obvious, and there was a huge expectation about the possibilities in the treatment of obesity. However, the situation in humans did not turn out quite as envisaged by the first leptin researchers. In contrast, it looks now as though it has its role in the mechanisms to protect the human fire of life during famine. The disruption in the hypothalamic-gonadal and other endocrine axes due to energy deficits with low levels of leptin leads to hypothalamic amenorrhea. Exogeneous injections of leptin have improved reproductive function and neuroendocrine function in women with low weight [11]. This study also showed that basic science sometimes really reshapes our understanding of the major biological systems as quickly and profoundly as the discovery of leptin has done. Thanks to the advances in the understanding of the molecular biology of adipose tissue we now have a better understanding of the regulation of the reproductive functions. The link was already known for a long time but not the underlying regulatory system.
What happens with the fire of life in humans with a chronic spinal cord injury? Levels of physical activity and NEAT are reduced to nearly zero while sympathetic nervous system activity is also very limited. Buchholz and Penchard report on the effects on energy expenditure in spinal cord injury patients. Obesity is a common secondary phenomenon in these persons and it is associated with adverse metabolic sequelae.

Finally, somewhat outside the scope of the fire of life theme of this section of Current Opinion in Clinical Nutrition and Metabolism is the paper of Melzer, Kayser and Pichard, summarizing the current findings on the effects of physical activity on human health. One of the criticisms of today's advice to increase physical activity to cope with the danger of weight gain and risks of disease is the increased risk of exposure to undesired side effects such as injuries, dehydration and cardiac arrest. The authors conclude that the risk exposure is outweighed by its overall benefits.

It is of interest to finish this editorial comment with a quote from the preface of the book by Kleiber. He described classical aspects of the animal energetics in his book as going 'out at a time when much of what is new today will be out by tomorrow. Some of the old knowledge, however, should not be forgotten.' We still can learn from this old knowledge about the fire of life.

\section{References}

1 Kleiber M. The fire of life. New York: John Wiley \& Sons Inc; 1961.

2 Darwin C. The origin of species. London: Wordsworth Editions Ltd; 1989 (originally 1859).

3 Neel JV. Diabetes Mellitus: a 'thrifty' genotype rendered detrimental by 'progress'. Am J Hum Genet 1960; 14:353-362.

4 Baxter K. Energy metabolism in animals and man. Cambridge: Cambridge University Press; 1989.

5 Bouchard C, Tremblay A, Depres JP, et al. The response to long-term overfeeding in identical twins. N Eng J Med 1990; 322:1477-1482.

6 Levine JA, Eberhard NL, Jensen MD. Role of non-exercise activity thermogenesis in resistance to fat gain in humans. Science 1999; 283:212-214.

7 Tremblay A, Depres JP, Theriault G, et al. Overfeeding and energy expenditure in humans. Am J Clin Nutr 1992; 56:857-862.

8 Ukkola O, Bouchard C. Role of candidate genes in the responses to longterm overfeeding: Review of findings. Obes Rev 2004; 5:2-12.

9 Saris WHM, Blair NS, Blaak van MA, et al. How much physical activity is needed to prevent unhealthy weight gain.? Outcome of the IASO $1^{\text {st }}$ Stock conference and consensus statement. Obes Rev 2003; 5:101-114.

10 Acheson K, Schutz Y, Bessard T, et al. Glyciogen storage capacity and the de-novo synthesis during massive carbohydrate overfeeding in man. Am J Clin Nutr 1988; 48:240-247.

11 Welt CK, Chan JL, Bullen J, et al. Recombinant human leptin in women with hypothalamic amenorrhea. N Eng J Med 2004; 351:987-997. 